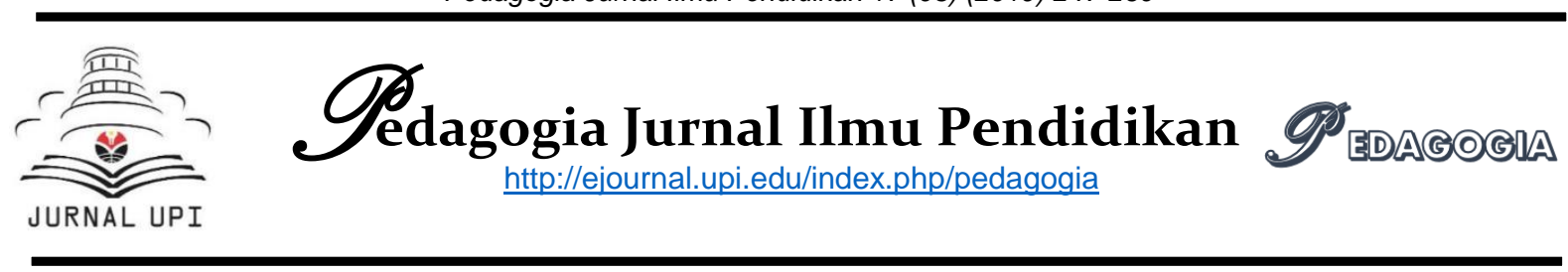

\title{
Pengaruh Struktural Analitik Sintetik Tergadap Peningkatan Membaca Permulaan Anak Cerebral Palsy
}

\author{
Ana Munandar \\ Nia Sutisna \\ Departemen Pendidikan Khusus \\ Fakultas Ilmu Pendidikan \\ Univeristas Pendidikan Indonesia \\ munandar.ana@gmail.com
}

\begin{abstract}
Pre-reading is the most basic and important ability to learn symbols or codes that have meaning and can be translated in sounds or sounds. The component of pre-reading is reading letters, syllables, words and simple sentences. Reading is very important for everyone, so are children with special needs. Cerebral Palsy is an individual who has permanent brain damage that affects mobilization, movement, communication, and so forth. The method used by teachers in schools is less able to improve pre-reading skills. Therefore, the subject requires learning methods that can improve the ability to read the beginning. One of them is the synthetic analytical structural learning method. This study uses this learning method to see the effect on early reading skills on the subject. The research method uses a quantitative approach, a single subject research experiment with A-B-A design. The number of sessions at $A 1$ is three sessions, $B$ is seven sessions, and $A 2$ is three sessions. The subjects of this study are spastic cerebral palsy children who have intelligence problems in class IX SMPLB. for each session the children obtained an average A1 value of 59.06\%, B $74.80 \%$, and $A 284.25 \%$. In conclusion, synthetic analytic structural methods can have a significant effect on improving early reading skills.
\end{abstract}

Keywords: Pre-Reading, Cerebral Palsy Structural, Synthetic Analytic

\footnotetext{
A bstrak

Membaca permulaan merupakan kemampuan paling dasar dan penting untuk mempelajari simbol atau kode yang memiliki makna serta dapat diterjemahkan dalam bunyi atau suara. Komponen membaca permulaan yaitu membaca huruf, suku kata, kata dan kalimat sederhana. Membaca sangat penting untuk setiap orang, begitu juga anak berkebutuhan khusus. Cerebral Palsy adalah individu yang mengalami kerusakan otak menetap yang berdampak pada mobilisasi, gerak, komunikasi, dan lain sebagainya. Metode yang digunakan oleh guru di sekolah kurang dapat meningkatkan kemampuan membaca permulaan. Oleh karena itu, subjek memerlukan metode pembelajaran yang dapat meningkatkan kemampuan membaca permulaannya. Salah satunya yaitu metode pembelajaran Strukrural Analitik Sintetik. Penelitian ini menggunakan metode pembelajaran ini untuk melihat pengaruh kepada kemampuan membaca permulaan pada subjek. Metode penelitian menggunakan pendekatan kuantitatif, eksperimen Single Subject Research dengan desain AB-A. Jumlah sesi pada A1 tiga sesi, B tujuh sesi, dan A2 tiga sesi. Subjek penelitian ini yaitu anak cerebral palsy spastik yang mengalami hambatan kecerdasan kelas IX SMPLB. etiap sesinya anak memperoleh rata-rata nilai A1 yaitu 59,06\%, B 74,80\%, dan A2 84,25\%. Kesimpulannya metode struktural analitik sintetik dapat berpengaruh signifikan terhadap peningkatan kemampuan membaca permulaan.
}

\author{
Article Info \\ Naskah Diterima : \\ 2019-10-25 \\ Naskah Direvisi: \\ 2019-12-28 \\ Naskah Disetujui: \\ 2020-03-18
}




\section{A. PENDAHULUAN}

Membaca merupakan hal paling penting untuk berkomunikasi dan membuka wawasan untuk menambah ilmu. Membaca merupakan proses menerima pesan yang terkandung dalam lambang-lambang yang tertulis. Hal ini dikemukakan oleh Tarigan (dalam Irdawati, dkk, 2011) bahwa membaca adalah suatu proses yang dilakukan serta dipergunakan oleh pembaca untuk menerima pesan, suatu metode yang dipergunakan untuk berkomunikasi dengan diri sendiri kadang-kadang orang lain, yaitu mengkomunikasikan makna yang terkandung atau tersirat pada lambang-lambang tertulis. Lebih singkatnya membaca adalah memetik serta memahami arti makna yang terkandung didalam bahan tulisan. Sedangkan menurut Hudson (dalam Tarigan, 2015, hlm. 6) mengemukakan bahwa membaca merupakan suatu proses yang menuntut agar kelompok kata yang merupakan satu kesatuan akan terlihat dalam suatu pandangan sekilas dan makna kata-kata secara individual akan dapat diketahui. Kalau hal ini tidak terpenuhi, pesan yang tersurat dan yang tersirat tidak akan tertangkap atau dipahami, dan proses membaca itu tidak terlaksana dengan baik.

Menurut pemaparan di atas, maka membaca merupakan hal terpenting dalam memulai sebuah pembelajaran dan menerima informasi serta melakukan komunikasi. Membaca menjadi modal penting dalam mempelajari sebuah materi atau teori. Menurut Irdawati, dkk (2011) dalam jurnalnya mengemukanan bahwa membaca adalah salah satu dari empat keterampilan berbahasa yang disajikan dalam pembelajaran Bahasa Indonesia selain keterampilan menyimak, keterampilan berbicara, dan ketrampilan menulis. Terlepas anak itu merupakan anak pada umumnya atau anak berkebutuhan khusus, keterampilan membaca harus dikuasai oleh anak.

Membaca dibagi kedalam dua tahapan, yaitu membaca permulaan dan membaca lanjutan. Menurut Baso, dkk (2012) bahwa membaca permulaan merupakan proses keterampilan menunjuk pada pengenalan dan penguasaan lambang-lambang fonem, sedangkan proses kognitif menunjuk pada penggunaan lambang-lambang, fonem yang sudah dikenal untuk memahami makna suatu kata yang dapat terangkai pada satu kalimat yang utuh dan dapat dimengerti maknanya. Membaca permulaan ini diajarkan kepada anak yang sudah mulai menginjak usia sekolah atau anak yang menginjak kelas 1 dan 2 sekolah dasar.

Sedangkan membaca lanjutan atau membaca pemahaman menurut Tarigan (dalam karya tulis Rosyana, 2015) adalah "membaca yang merujuk pada jenis kegiatan membaca dalam hati yang dilakukan untuk memperoleh pengertian tentang sesuatu atau untuk tujuan belajar sehingga memperoleh wawasan yang lebih luas tentang sesuatu yang dibaca." Prasyarat membaca lanjutan ini adalah anak harus mampu menguasai membaca permulaan. Kemampuan anak cerebral palsy kelas IX SMPLB harusnya sudah memiliki kemampuan membaca pemahaman, tetapi pada kasus ini, anak tersebut masih pada tahap membaca permulaan. Menurut penuturan guru kelasnya, subjek diduga mengalami hambatan kecerdasan walaupun belum ada pemeriksaan lebih lanjut. Hal ini dilihat dari kemampuan anak saat belajar.

Metode pembelajaran yang dilakukan oleh guru belum dapat meningkatkan kemampuan membaca permulaan anak. Berdasarkan hasil pengamatan di lapangan, guru menggunakan metode eja yang 
digabungkan dengan menulis untuk latihan motorik.

Berdasarkan permasalahan di atas, maka anak membutuhkan metode pembelajaran membaca permulaan. Salah satunya, peneliti anak menguji metode pembelajaran Struktural Analitik Sintetik (SAS). Menurut ahli dan berbagai penelitian mengemukakan bahwa metode pembelajaran ini dapat meningkatkan kemampuan membaca permulaan pada anak tipikal. Maka dari itu, peneliti akan mencoba melakukan penelitian terhadap metode pembelajaran SAS ini terhadap anak cerebral palsy melalui metode Single Subject Resert (SSR). Apakah metode Struktural Analitik Sintetik ini berpengaruh terhadap kemampuan membaca permulaan anak cerebral palsy tipe spastik yang diiringi hambatan kecerdasan atau tidak.

\section{B. KAJIAN PUSTAKA}

\section{Cerebral Palsy}

Anak cerebral palsy merupakan anak yang tidak mampu melakukan mobilitas atau melakukan gerak yang diakibatkan oleh kerusakan pada otak. Hal tersebut dikemukakan oleh Phelp (dalam Muslim, dkk, 1996, hlm 68) bahwa anak cerebral palsy merupakan anak yang mengalami hambatan dalam motoriknya yang diakibatkan kelayuhan pada bagian otak yang berdampak pada otot, tulang, dan persendian. Cerebral Palsy adalah suatu kelainan pada gerak tubuh yang ada hubungannya dengan kerusakan otak yang menetap. Akibatnya otak tidak berkembang, tetapi bukan suatu penyakit yang progresif.

Akibatnya anak tidak mampu melakukan mobilitas atau melakukan gerak. Tipe cerebral palsy sendiri sangat banyak, tergantung hambatan yang dialaminya. Salah satunya adalah cerebral palsy tipe spastik quadriplegia. Anak cerebral palsy ini ada yang diiringi oleh hambatan kecerdasan, sehingga anak cerebral palsy mengalami hambatan dalam akademik seperti membaca, menulis dan berhitung. Anak cerebral palsy juga terganggu pada hal komunikasinya (bahasa) yang kadang berdampak pada ketidakmampuan anak dalam menyampaikan apa yang dia ingin sampaikan baik berupa tulisan maupun lisan.

Kemampuan anak kelas IX SMPLB harusnya sudah memiliki kemampuan membaca pemahaman, tetapi pada kasus ini, anak tersebut masih pada tahap membaca permulaan. Menurut penuturan guru kelasnya, subjek diduga mengalami hambatan kecerdasan walaupun belum ada pemeriksaan lebih lanjut. Hal ini dilihat dari kemampuan anak saat belajar. Kemampuan siswa dalam membaca permulaan menurut hasil pengamatan, siswa sudah bisa menyebutkan hurufhuruf abjad walaupun kadang lupa ketika ditanya dan sudah bisa mengeja huruf dengan pola konsonan vokal (KV) hanya beberapa huruf saja. Kemampuan subjek dalam membaca permulaan dari segi fisik yang ia tidak mengalami hambatan seperti hambatan penglihatan, hambatan pendengaran dan hambatan dalam pengucapan. Hanya saja dalam pengucapan volume suara yang kadang keras dan kadang kecil serta pengucapan kurang jelas.

\section{Membaca Permulaan}

Membaca permulaan belum memiliki kemampuan membaca sesungguhnya, tetapi pada tingkatan ini pembaca masih dalam tahap belajar untuk memperoleh kemampuan membaca. Pada tingkatan ini membaca hanya sebatas memperoleh kemampuan untuk membunyikan lambang-lambang tulis tersebut dengan bunyi. Menurut Baso, dkk (2012) bahwa membaca permulaan merupakan suatu proses keterampilan dan kognitif. Proses keterampilan menunjuk pada pengenalan 
dan penguasaan lambang-lambang fonem, sedangkan proses kognitif menunjuk pada penggunaan lambanglambang fonem yang sudah dikenal untuk memahami makna suatu kata yang dapat terangkai pada satu kalimat yang utuh dan dapat dimengerti maknanya. Pembelajaran membaca permulaan diberikan di kelas I.

Membaca permulaan merupakan tingkatan paling dasar. Hal tersebut diungkapkan oleh Darwadi (dalam Styandhani, 2015, hlm. 10) yaitu 'membaca permulaan merupakan tahap awal dalam belajar membaca yang difokuskan dalam mengenal simbol-simbol atau tanda-tanda yang berkaitan dengan huruf-huruf sehingga menjadi pondasi agar anak dapat melanjutkan ke tahap membaca. Sejalan dengan pemaparan di atas, Abidin (2010, hlm. 115) mengemukakan bahwa "membaca permulaan ialah proses recording dan decoding". Proses Recoding adalah rangkaian tulisan yang dibaca menjadi rangkaian bunyi bahasa, menjadi rangkaian huruf membentuk kata, kelompok kata, dan kalimat sederhana. Sedangkan proses decoding adalah bentuk-bentuk bunyi dan rangkaian diidentifikasi, diuraikan lalu bermakna.

Berdasarkan pemaparan di atas, dapat disimpulkan bahwa membaca permulaan merupakan kemampuan paling dasar atau awal untuk mempelajari simbol atau kode yang memiliki makna serta dapat diterjemahkan dalam bunyi atau suara. Syarat dalam membaca permulaan ini adalah membunyikan lambang tulis, penguasaan kosa kata menjadi arti dan memasukkan makna dalam kemahiran bahasa. Tujuannya adalah agar siswa memiliki kemampuan memahami dan menyuarakan tulisan dengan intonasi yang wajar, sebagai dasar untuk dapat membaca lanjut. Pembelajaran membaca permulaan merupakan tingkatan proses pembelajaran membaca untuk menguasai sistem tulisan sebagai representasi visual bahasa. Tingkatan ini sering disebut dengan tingkatan belajar. Sedangkan membaca lanjut merupakan tingkatan proses penguasaan membaca untuk memperoleh isi pesan yang terkandung dalam sebuah tulisan. Tingkatan ini disebut sebagai membaca untuk belajar.

\section{Metode Pembelajaran Strukrural Analitik Sintetik}

Menurut teori, metode pembelajaran SAS ini digunakan oleh guru untuk mengajarkan membaca permulaan pada anak, walaupun banyak metode lain yang dapat digunakan dalam mengajarkan membaca permulaan ini. Kelebihan dari metode ini adalah anak dapat menganalisis struktur kalimat, kata, suku kata dan huruf dengan seksama dari kejadian kehidupan sehari-harinya, sehingga dengan hal tersebut akan menjadi mudah dalam memahami huruf, suku kata, kata dan kalimat yang ia pelajari.

Metode pembelajaran SAS (Struktural Analitik Sintetik) adalah metode yang disediakan untuk belajar membaca dan menulis permulaan di kelas permulaan SD. Menurut Supriyadi (1992) mengemukakan bahwa metode SAS adalah suatu metode yang memulai pengajaran dengan menampilkan struktur kalimat secara utuh itu dianalisis dan pada akhirnya dikembalikan pada bentuk semula. Dengan demikian maka proses operasional metode SAS memiliki langkah-langkah yang berlandaskan operasional dengan urutan struktural metampilkan keseluruhan, analitik melakukan proses penguraian, sintetik melakukan penggabungan kembali kepada bentuk struktural semula.

Solchan, dkk., (dalam Setyani. W, 2012) mengemukakan bahwa metode SAS memiliki beberapa prinsip, yaitu prinsip lingustik (ilmu bahasa) yang memandang satuan bahasa terkecil untuk 
berkomunikasi adalah kalimat. Kalimat dibentuk oleh satuan-satuan bahasa di bawahnya yakni kata, suku kata, dan fonem (huruf-huruf); metode SAS juga mempertimbangkan pengalaman berbahasa anak.

Oleh karena itu, pengajaran akan lebih bermakna bagi anak karena bertolak dari sesuatu yang dikenal dan diketahui anak. Hal ini akan memberikan dampak positif terhadap daya ingat dan pemahaman anak; prinsip inkuiri (mentemukan sendiri). Anak mengenal dan memahami sesuatu berdasarkan hasil temuannya sendiri. Sikap seperti ini akan membantu anak dalam mencapai keberhasilan belajar.

Baso dkk (2012), mengemukaan bahwa pelaksanaannya, metode SAS dibagi dalam dua tahap, yakni: tanpa buku, dan menggunakan buku. Pada tahap tanpa buku, pembelajaran membaca permulaan dilaksanakan dengan cara-cara sebagai berikut.

1. Membaca tanpa buku

a. Merekam bahasa siswa

Bahasa yang digunakan oleh siswa di dalam percakapan mereka, direkam untuk digunakan sebagai bahan bacaan. Karena bahasa yang digunakan sebagai bahan bacaan adalah bahasa siswa sendiri maka siswa tidak akan kesulitan.

b. Menampilkan gambar sambil bercerita

Pada tahap ini, guru memperlihatkan gambar kepada siswa, sambil bercerita sesuai dengan gambar tersebut. Kalimatkalimat yang digunakan guru dalam bercerita itu digunakan sebagai pola dasar bahan membaca. Contoh : guru memperlihatkan gambar seorang anak yang sedang menulis, sambil bercerita.

Misalnya : Ini Adi. Adi duduk di kursi. la sedang menulis surat. Kalimat-kalimat guru tersebut ditulis di papan tulis dan digunakan sebagai bahan bacaan.

c. Membaca gambar

Guru memperlihatkan sebuah gambar di papan tulis. Misalnya gambar seorang ibu yang sedang memegang sapu, sambil mengucapkan kalimat. "Ini ibu". Siswa melanjutkan membaca gambar tersebut dengan bimbingan guru.

d. Membaca gambar dengan kartu kalimat

Setelah siswa dapat membaca gambar dengan lancar, guru menempatkan kartu kalimat di bawah gambar. Untuk memudahkan pelaksanaannya dapat digunakan media berupa papan selip atau papan flanel, kartu kalimat, kartu kata, kartu huruf, dan kartu gambar. Dengan menggunakan kartu-kartu dan papan selip atau papan flanel, untuk menguraikan dan menggabungkan kembali akan lebih mudah.

e. Membaca kalimat secara struktural (S)

Setelah siswa dapat membaca tulisan di bawah gambar, sedikit demi sedikit gambar dikurangi sehingga akhirnya mereka dapat membaca tanpa bantuan gambar. Dalam kegiatan ini yang digunakan kartu-kartu kalimat serta papan flanel. Dengan dihilangkannya gambar, yang dibaca siswa adalah kalimat. Misalnya:

Ini bola.

Ini bola Adi.

Ini bola Ali.

Ini bola Santi

f. Proses analitik (A)

Setelah siswa dapat membaca kalimat, mulailah menganalisis kalimat itu menjadi kata, kata menjadi suku kata, dan suku kata menjadi huruf. 
Misalnya:

$$
\text { Ini bola }
$$

Ini bola

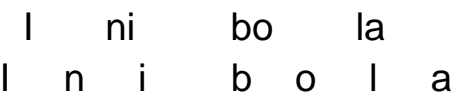

g. Proses sintetik (S)

Setelah siswa mengenal hurufhuruf dalam kalimat yang diuraikan, hurufhuruf itu dirangkaikan lagi menjadi suku kata, suku kata menjadi kata, dan kata menjadi kalimat seperti semula. Misalnya:

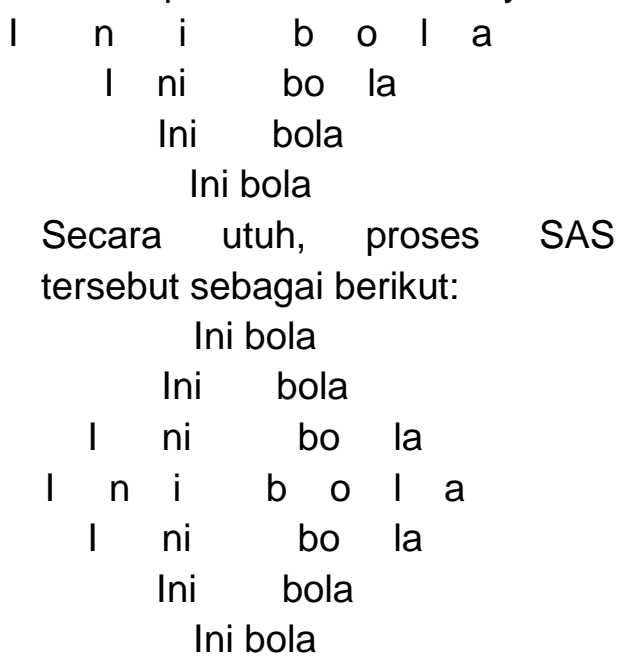

2. Membaca dengan buku

Kegiatan membaca dengan buku selalu bertitik tolak dari 3 kegiatan pokok metode SAS, yang meliputi memperkenalkan struktur, menganalisis, dan mensintesiskan kembali.

Membaca dengan menggunakan buku siswa akan memulai membaca tulisan yang bahannya diambil dari bahan yang telah dipelajari pada waktu murid menguraikan huruf-huruf pada saat membaca tanpa buku. Buku yang digunakan adalah buku paket dan buku pelengkap. Pengajaran berulang dengan kegiatan sebagai berikut.

a. Memberikan contoh cara membaca pola kalimat yang tersedia dengan lafal dan intonasi yang baik dan benar.

b. Membaca dengan nyaring bacaan secara bersama-sama. c. Membaca setiap baris kalimat secara bergantian. Dengan melakukan cara ini guru dapat mengetahui kemampuan membaca siswanya.

d. Membaca dengan menggunakan lafal dan intonasi yang tepat. Bila dinilai, anak belum mampu mengenal huruf pergunakan kembali kartu-kartu kalimat, kata dan huruf yang pernah dipakai dalam kegiatan membaca tanpa buku.

\section{METODE PENELITIAN}

Metode penelitian yang digunakan adalah metode eksperimen dengan rancangan Single Subject Research $(S S R)$, dengan pola desain tunggal penelitian pada bidang modifikasi perilaku dengan kategori desain dengan pengulangan yaitu A-B-A. Menurut Sugiono (2016, hlm. 107), metode penelitian eksperimen dapat diartikan sebagai metode penelitian yang digunakan untuk mencari pengaruh perlakuan terhadap yang lain dalam kondisi yang dikendalikan. Penelitian ini menggunakan subjek tunggal (SSR) untuk mengetahui peningkatan kemampuan membaca permulaan peserta didik cerebral palsy. Adapun desain single subject research yang digunakan adalah design $A-B-A$ yang terbagi dalam tiga kondisi yaitu (A-1) sebagai kondisi awal kemampuan dasar kemampuan membaca permulaan yang akan diteliti, B merupakan kondisi pemberian intervensi untuk meningkatkan kemampuan membaca permulaan dengan benar, (A-2) kondisi kemampuan membaca permulaan setelah diberikan intervensi. Desain ini menunjukkan adanya sebab akibat antar kondisi.

Secara umum desain A-1 (baseline 1), B (intervensi), A-2 (baseline 2) adalah sebagai berikut: 
Tabel 1

Tampilan desain A-B-A

\begin{tabular}{ccc}
\hline Baseline-1 (A-1) & Intervensi (B) & Baseline-2 (A-2) \\
\hline O ○ O & $\times \times X$ & \\
$(3$ sesi $)$ & $\times \times \times \times$ & O ० \\
& $(7$ sesi $)$ & $(3$ sesi $)$ \\
\hline
\end{tabular}

1. A-1 (baseline 1) yaitu kondisi kemampuan dasar, dimana pengukuran target behavior dilakukan pada keadaan naturan sebelum diberikan perlakuan atau treatment apapun. Dalam penelitian ini kemampuan yang akan diungkapkan adalah kemampuan membaca permulaan. Subjek diamati sehingga dalam kondisi kemampuan awal subjek tersebut dapat diambil data tanpa adanya rekayasa. Pengamatan dan pengambilan data dilakukan secara berulang untuk memastikan data yang didapatkan berupa kemampuan dasar subjek dalam membaca permulaan. Pada fase ini dilakukan sebanyak tiga sesi.

2. B (intervensi) yaitu kondisi subjek penelitian selama diberikan perlakuan, dalam hal ini adalah untuk meningkatkan kemampuan membaca permulaan yang menggunakan metode pembelajaran struktural analitik sintetik. Fase ini dilakukan tujuh sesi.

3. A-2 (Baseline 2) yaitu pengamatan tanpa intervensi yang dilakukan subjek diberikan intervensi atau perlakuan. Disamping sebagai control dari kegiatan intervensi, baseline ini juga berfungsi sebagai tolak ukur keberhasilan dan sebagai evaluasi untuk melihat sejauh mana intervensi yang diberikan berpengaruh pada subjek. Pengamatan dilakukan untuk melihat kemampuan membaca permulaan pada subjek. Fase ini dilakukan sebanyak tiga sesi. Subjek dalam penelitian ini yaitu seorang siswa dengan hambatan cerebral pasly tipe spastik quadriplegia ringan yang juga disertai dengan hambatan kecerdasan di SLB Risantya. Adapun identitas siswa tersebut sebagai berikut:

$\begin{array}{ll}\text { Nama/Inisial } & : \text { HT } \\ \text { Usia } & : 14 \text { tahun } \\ \text { Jenis kelamin } & : \text { Laki-laki } \\ \text { Kelas } & : \text { IX SMPLB } \\ \text { Sekolah } & : \text { SLB Risantya }\end{array}$

Subjek merupakan anak laki-laki yang berusia 14 tahun dan sekarang duduk di kelas IX SMPLB Risantya Bandung. Hambatan yang dialami oleh anak yaitu cerebral palsy spastik quadriplegia ringan yang disertai dengan hambatan kecerdasan.

Kekakuan terdapat pada semua anggota gerak anak, yaitu pada kedua kaki dan kedua tangannya tetapi anak mampu bergerak tanpa alat bantu. Pada saat ini anak melakukan terapis dalam memperbaiki motorik kasar supaya tidak terjadi kekakuan dan melatih motorik halusnya dengan berbagai metode oleh terapisnya. Aspek bicara (organ artikulasi) subjek mengalami sedikit kekakuan, sehingga dalam berbicara subjek sedikit tidak jelas, akan tetapi masih dimengerti oleh lawan bicara.

Perkembangan akademik anak terhambat seperti dalam perkembangan menghitung, membaca dan menulis. Perkembangan berhitung, subjek baru sampai kepada tahap menghitung dua digit angka. Perkembangan membaca, subjek baru mampu membaca huruf vokal dan konsonan serta beberapa suku kata 
yang berpola tertentu, seperti konsonan vokal (KV), dan konsonan vokal konsonan vokal (KVKV) serta beberapa kata yang berpola tertentu dengan dieja. Perkembangan menulis, subjek baru sampai latihan menebalkan objek atau menebalkan huruf. Perlu peningkatanpeningkatan lebih lanjut pada berbagai aspek tersebut. Peneliti memfokuskan pada aspek membaca permulaan anak.

Pengumpulan data dilakukan dengan melakukan tes kemampuan membaca permulaan kepada subjek dengan lembar instrumen yang sudah divalidasi oleh ahli. Tes dilakukan pada baseline A1, B yang dilakukan setelah melakukan intervensi atau perlakukan pada setiap sesinya, dan baseline A2 seperti yang telah dipaparkan di atas. Analisis data dapat dilakukan dengan dua cara yaitu analisis dalam kondisi dan analisis antar kondisi.

\section{HASIL DAN PEMBAHASAN}

Berdasarkan hasil penelitian yang telah dilakukan berdasarkan insturmen yang dibuat, subjek memperoleh nilai sebagai berikut. Adapun komponen 1 merupakan kemampuan membaca huruf, komponen 2 merupakan kemampuan membaca suku kata, komponen 3 merupakan kemampuan membaca kata, dan komponen 4 merupakan kemampuan membaca kalimat sederhana.

Tabel 2

Rekapitulasi Data Setiap Sesi

\begin{tabular}{|c|c|c|c|c|c|c|c|}
\hline \multirow{2}{*}{ Fase } & \multirow{2}{*}{ Sesi } & \multicolumn{4}{|c|}{ Komponen } & \multirow{2}{*}{$\begin{array}{l}\text { Total } \\
\text { Skor }\end{array}$} & \multirow{2}{*}{$\begin{array}{c}\text { Hasil/Nilai } \\
\text { (\%) }\end{array}$} \\
\hline & & 1 & 2 & 3 & 4 & & \\
\hline \multirow{3}{*}{$\begin{array}{l}\text { Baseline } 1 \\
\text { (A1) }\end{array}$} & 1 & 50 & 8 & 11 & 0 & 69 & $54,33 \%$ \\
\hline & 2 & 51 & 14 & 11 & 1 & 77 & $60,63 \%$ \\
\hline & 3 & 51 & 16 & 11 & 1 & 79 & $62,20 \%$ \\
\hline \multirow{7}{*}{$\begin{array}{l}\text { Intervensi } \\
\text { (B) }\end{array}$} & 4 & 53 & 23 & 11 & 2 & 89 & $70,08 \%$ \\
\hline & 5 & 53 & 25 & 11 & 2 & 91 & $71,65 \%$ \\
\hline & 6 & 54 & 24 & 11 & 1 & 90 & $70,87 \%$ \\
\hline & 7 & 55 & 27 & 12 & 1 & 95 & $74,80 \%$ \\
\hline & 8 & 55 & 28 & 14 & 1 & 98 & $77,17 \%$ \\
\hline & 9 & 54 & 29 & 15 & 2 & 100 & $78,74 \%$ \\
\hline & 10 & 56 & 28 & 16 & 2 & 102 & $80,31 \%$ \\
\hline \multirow{3}{*}{$\begin{array}{c}\text { Baseline } 2 \\
\text { (A2) }\end{array}$} & 11 & 56 & 28 & 17 & 2 & 103 & $81,10 \%$ \\
\hline & 12 & 56 & 31 & 18 & 2 & 107 & $84,25 \%$ \\
\hline & 13 & 56 & 33 & 19 & 3 & 111 & $87,40 \%$ \\
\hline
\end{tabular}

Sumber : Penelitian kemampuan membaca permulaan, 2019

Sesuai dengan tabel 2 , berikut grafik untuk menggambarkan progres kemampuan membaca permulaan selama penelitian. 


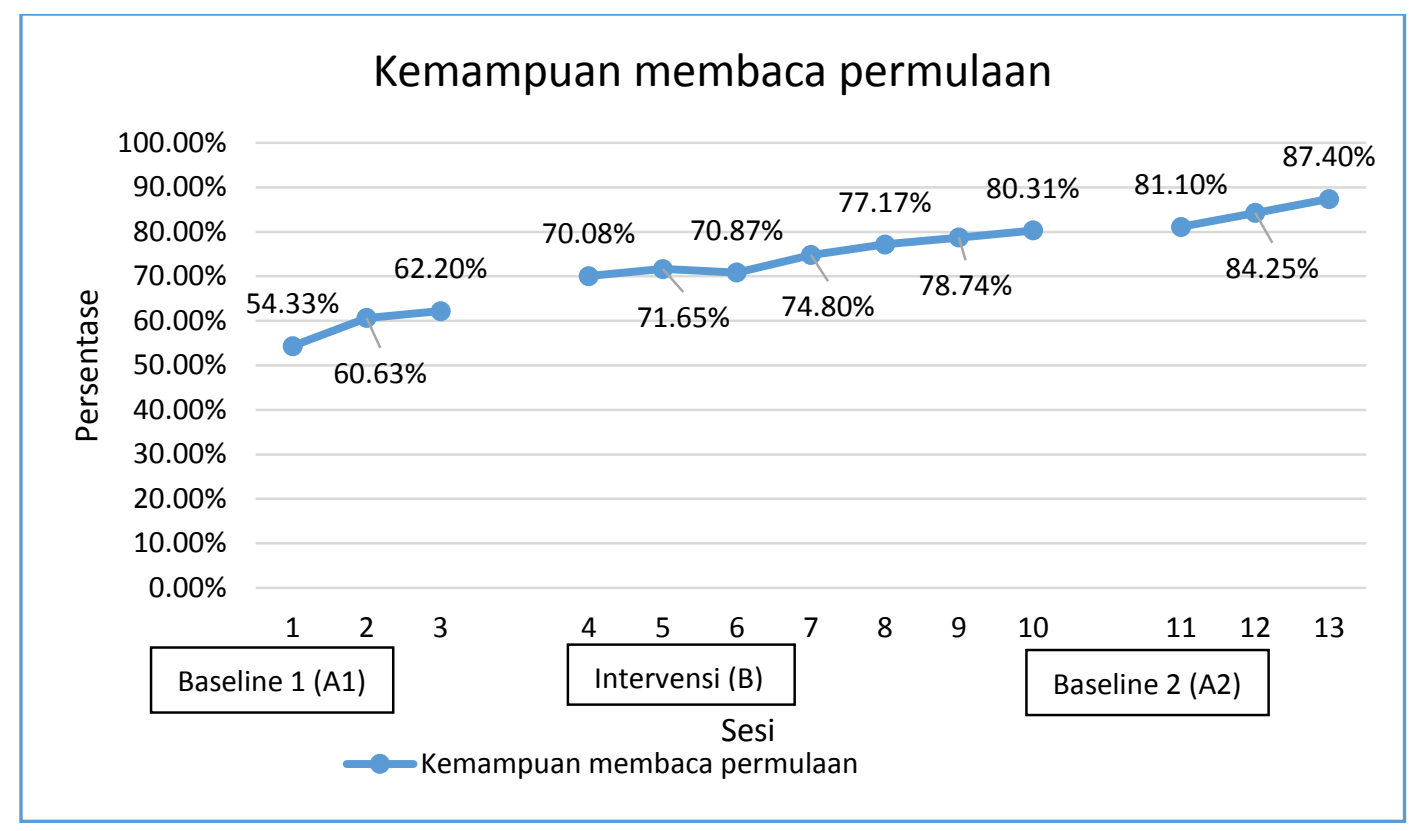

\section{Gambar 1}

Rekapitulasi Data Kemampuan Membaca Permulaan

Selain pada grafik garis di atas, peningkatan kemampuan membaca permulaan subjek dengan cerebral palsy spastik dapat dilihat dari grafik batang mean level setiap fase sebagi berikut :

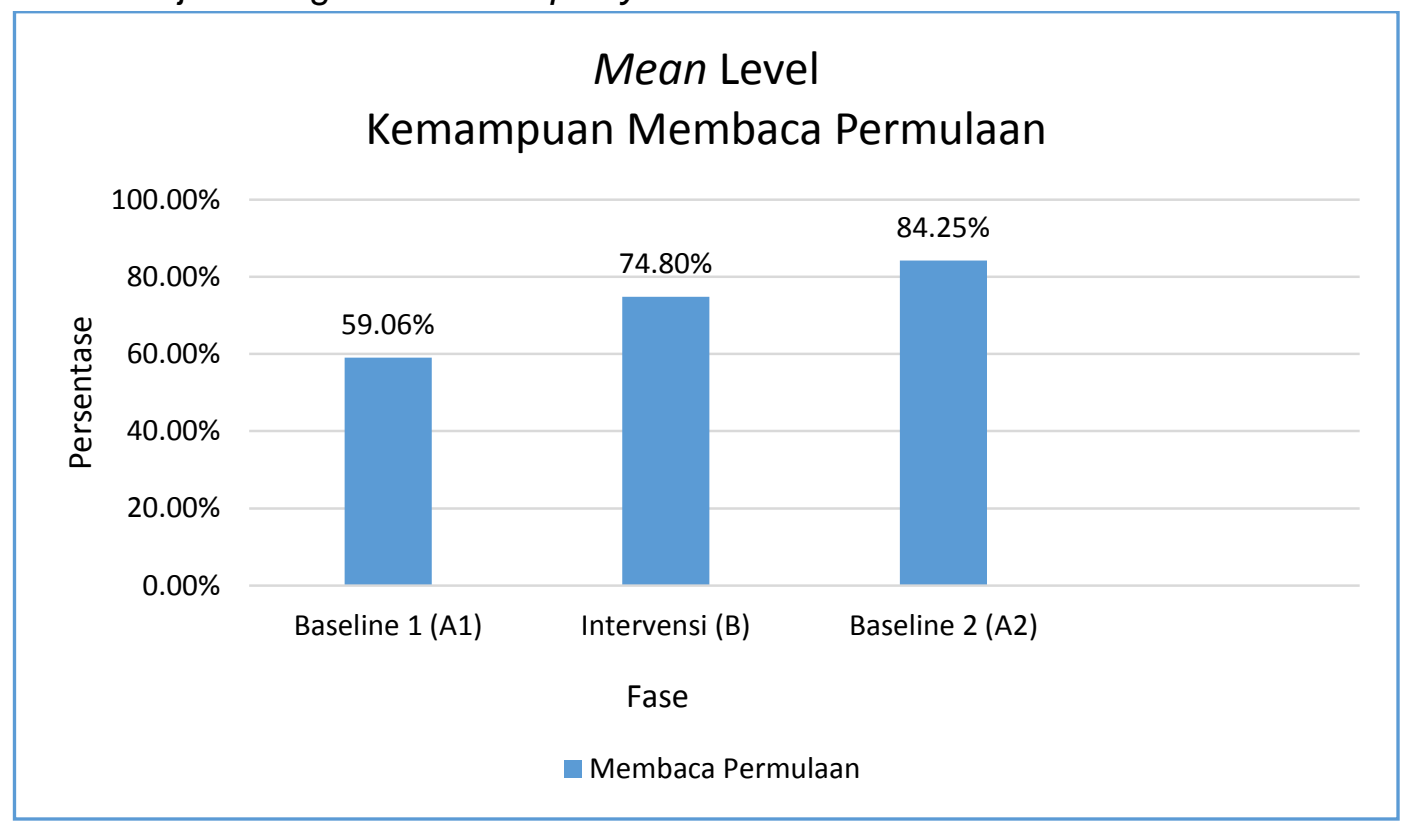

\section{Gambar 2}

Grafik Mean Level Kemampuan Membaca Permulaan

Analisis data yang dilakukan oleh peneliti dalam kondisi dan antar kondisi adalah sebagai berikut : 
Tabel 3

Rangkuman Hasil Analisis Visual dalam Kondisi

\begin{tabular}{|c|c|c|c|}
\hline Fase & Baseline 1 (A1) & Intervensi (B) & Baseline 2 (A2) \\
\hline $\begin{array}{l}\text { Panjang } \\
\text { Kondisi }\end{array}$ & 3 & 7 & 3 \\
\hline $\begin{array}{c}\text { Kecenderungan } \\
\text { arah }\end{array}$ & $(+)$ & $(+)$ & $(+)$ \\
\hline $\begin{array}{c}\text { Kecenderungan } \\
\text { stabilitas }\end{array}$ & $\begin{array}{c}67 \% \\
\text { (Stabil) }\end{array}$ & $\begin{array}{c}100 \% \\
(\text { Stabil) } \\
\end{array}$ & $\begin{array}{l}100 \% \\
(\text { Stabil) } \\
\end{array}$ \\
\hline Jejak Data & $(+)$ & $(+)$ & $(+)$ \\
\hline $\begin{array}{l}\text { Level stabilitas } \\
\text { dan rentang }\end{array}$ & $\frac{\text { Stabil }}{54,33 \%-62,20 \%}$ & $\frac{\text { Stabil }}{70,08 \%-80,31 \%}$ & $\frac{\text { Stabil }}{81,10 \%-87,40 \%}$ \\
\hline $\begin{array}{c}\text { Perubahan } \\
\text { Level }\end{array}$ & $\frac{62,20 \%-54,33 \%}{(+7,87 \%)}$ & $\frac{80,31 \%-70,08 \%}{(+10,24 \%)}$ & $\frac{87,40 \%-81,10 \%}{(+6,30 \%)}$ \\
\hline
\end{tabular}

Sumber : Analisis Data dalam Kondisi, 2019

Rangkuman penjelasan hasil analisis visual dalam kondisi adalah sebagai berikut :

1. Panjang kondisi atau banyaknya sesi yang dilaksanakan pada penelitian ini untuk mengukur kemampuan membaca permulaan subjek adalah tiga sesi pada fase baseline 1 (A1), tujuh sesi pada fase intervensi $(B)$, dan tiga sesi pada fase baseline 2 (A2).

2. Berdasarkan estimasi garis kecenderungan arah, diketahui hasil dari kecenderungan arah pada penelitian ini yaitu pada fase baseline 1 (A1) meningkat atau stabil (+), hal ini menunjukan bahwa kondisi awal subjek rubah sebelum medapatkan intervensi. Pada fase intervensi meningkat (+), hal tersebut menunjukan bahwa pemberian intervensi $\quad$ (B) mempengaruhi kemampuan membaca permulaan subjek ke arah yang baik. Pada fase baseline 2 (A2) meningkat (+) hal tersebut menunjukan bahwa setelah pemberian intervensi kondisi subjek masih berubah ke arah yang baik. Maka, kemampuan membaca permulaan subjek pada penelitian ini membaik.

3. Kecenderungan stabilitas diperoleh dari hasil pada fase baseline 1 (A1) stabil dengan persetase $67 \%$, pada fase intervensi (B) stabil dengan persentase $100 \%$ dan fase baseline 2 (A2) stabil dengan persentase 100\%. Data tersebut menujukan bahwa data yang diperoleh pada penelitian ini stabil.

4. Jejak data pada penelitian ini dilihat dari garis kecenderungan meningkat atau menaik, maka dapat diketahui jejak data penelitian ini meningkat dalam arti membaik.

5. Level stabilitas pada ketiga fase menunjukan bahwa pada baseline 1 (A1) rentang stabilitas yaitu $54,33 \%$ sampai dengan $62,20 \%$. Pada fase intervensi (B) datanya stabil dengan rentang $70,08 \%$ sampai dengan $80,31 \%$. Pada fase baseline 2 (A2) datanya stabil dengan rentang $81,10 \%$ sampai dengan $87,40 \%$.

6. Perubahan level pada setiap fase menunjukan data stabil pada fase baseline 1 (A1) $(+)$ dengan nilai perubahan level $+7,37 \%$, peningkatan data pada fase intervensi (B) (+) 
sebesar $+10,34 \%$, dan peningkatan data pada fase baseline 2 (A2) (+) sebesar $+6,30 \%$. Perubahan level paling banyak terjadi pada fase intervensi.

Tabel 4

Rangkuman Analisis Data Visual Antar Kondisi

\begin{tabular}{|c|c|c|}
\hline \multirow{2}{*}{ Perbandingan Fase } & $B$ & $\underline{A 2}$ \\
\hline & $\overline{A 1}$ & $\bar{B}$ \\
\hline Jumlah Variabel diubah & 1 & 1 \\
\hline \multicolumn{3}{|l|}{$\begin{array}{c}\text { Perubahan Kecenderungan } \\
\text { arah dan efeknya }\end{array}$} \\
\hline & $(+)$ & $(+) \quad(+)$ \\
\hline $\begin{array}{l}\text { Perubahan Kecenderungan } \\
\text { Stabilitas }\end{array}$ & $\begin{array}{l}\text { Stabil } \\
\text { Ke } \\
\text { Stabil }\end{array}$ & $\begin{array}{c}\text { Stabil } \\
\text { Ke } \\
\text { Stabil }\end{array}$ \\
\hline Perubahan Level & $\begin{array}{c}70,08 \%-62,20 \% \\
(+7,87 \%) \\
\text { Meningkat }\end{array}$ & $\begin{array}{c}81,10 \%-80,31 \% \\
(+0,79) \\
\text { Meningkat }\end{array}$ \\
\hline Persentase Overlap & $\frac{0}{7} \times 100 \%=0 \%$ & $\frac{0}{3} \times 100 \%=0 \%$ \\
\hline
\end{tabular}

Sumber : Analisis Data Antar Kondisi, 2019

Penjelasan dari analisis visual antar kondisi penelitian ini adalah sebagai berikut.

1. Jumlah variabel yang diubah adalah 1, yaitu kemampuan membaca permulaan subjek pada fase baseline 1 (A1) ke fase intervesi (B).

2. Kecenderungan arah antar kondisi pada fase baseline 1 (A1) ke fase intervensi (B) adalah meningkat ke meningkat, hal tersebut menunjukan kemampuan membaca permulaan subjek semakin membaik begitu diberikan intervensi. Kemudian kecenderungan arah dari fase intervensi (B) ke fase baseline 2 (A2) juga meningkat dan meningkat, hal tersebut menunjukan kemampuan membaca permulaan subjek membaik selepas penerapan intervensi.

3. Perubahan kecenderungan stabilitas antara baseline 1 (A1) ke intervensi $(B)$ dan intervensi (B) ke baseline 2 (A2) adalah stabil ke stabil. Perubahan level antara fase baseline 1 (A1) ke fase intervensi (B) adalah meningkat sebanyak $+7,87 \%$ dan fase intervensi (B) ke fase baseline 2 (A1) adalah meningkat sebesar $+0,79$.

4. Data overlap dari fase baseline 1 (A1) ke fase intervensi (B) adalah $0 \%$ dan fase intervensi (B) ke fase baseline 2 (A2) adalah $0 \%$. Hal tersebut menunjukan bahwa intervensi berpengaruh pada kemampuan membaca permulaan subjek.Pada penelitian ini, penulis menggunakan metode pembelajaran struktural analitik sintetik sebagai materi pada program intervensi untuk subjek yang dilakukan satu sesi dalam sehari selama dua jam pelajaran dengan tujuan mengetahui pengaruh terhadap peningkatan kemampuan membaca permulaan subjek. Metode pembelajaran struktural analitik sintetik merupakan suatu metode yang memulai pengajaran dengan menampilkan struktur kalimat secara utuh itu dianalisis dan pada akhirnya dikembalikan pada bentuk 
semula. Dengan demikian maka proses operasional metode ini mempunyai langkah-langkah berlandaskan operasional dengan urutan: Struktural metampilkan keseluruhan; Analitik melakukan proses penguraian; Sintetik melakukan penggabungan kembali kepada bentuk struktural semula.

Setelah melakukan penelitian selama tiga belas sesi yang meliputi tiga sesi pada fase baseline 1 ( $A 1$ ), tujuh sesi pada fase intervensi $(B)$ dan tiga sesi pada fase baseline 2 (A2). Penulis dapat melihat perubahan yang terjadi pada kemampuan membaca permulaan subjek adalah meningkat. Semakin besar persentase yang dicapai subjek pada instrumen membaca permulaan menggambarkan kondisi yang semakin membaik. Peningkatan tersebut dapat terlihat dari analis visual grafik yang dilakukan.

Pada fase baseline 1 (A1) yang merupakan keadaan awal kemampuan membaca permulaan subjek, diketahui bahwa kondisi subjek dimana kemampuan membaca permulaan subjek masih rendah, yaitu kemampuan membaca huruf yang menjadi modal dalam membaca suku kata, kata dan kalimat masih ada beberapa huruf yang belum anak bisa terutama pada huruf ganda seperti 'ng', 'ny', 'ai', 'au', dan 'oi'. Subjek juga belum mampu membaca suku kata dengan beberapa pola yaitu membaca suku kata yang berpola vokal konsonan (VK), konsonan vokal konsonan (KVK), konsonan vokal konsonan vokal konsonan (KVKVK), konsonan vokal konsonan konsonan vokal (KVK-KV), konsonan vokal onsonan konsonan vokal konsonan (KVK-KVK), konsonan vokal konsonan vokal konsonan vokal (KVKVKV). Subjek juga belum mampu membaca kata benda yang berpola KVK-KV, kata kerja berpola KVKVK, kata sifat berpola KVKKVK. Serta subjek belum mampu membaca kalimat sederhana terdiri dari dua kata, tiga kata dan empat kata, serta kalimat sederhana yang SPOK.

Fase intervensi (B) merupakan fase untuk menerapkan program intervensi yang telah disiapkan. Perubahan persentase kemampuan membaca permulaan sangat terlihat sejak sesi pertama dan kedua penerapan program intervensi. Selanjutnya kemampuan membaca permulaan mengalami penurunan pada sesi ke tiga. Sesi ke empat sampai sesi ke tujuh terus meningkat sedikit demi sedikit. Selama kegiatan intervensi, kemampuan membaca permulaan subjek mengalami peningkatan. Hal tersebut menunjukan bahwa penerapan program intervensi metode pembelajara struktural analitik sintetik mempengaruhi peningkatan kemampuan membaca permulaan subjek dengan cukup signifikan.

Pada fase baseline 2 (A2) yang merupakan pengukuran kembali kemampuan membaca permulaan subjek selepas pemberian intervensi menunjukan persentase hasil yang stabil. Hal tersebut menunjukan hasil dari penerapan program intervensi cukup baik. Hal tersebut ditunjukan oleh persentase kemampuan membaca permulaan subjek yang tidak kembali menurun selepas dari penerapan program intervensi.

Persentase mean pada fase baseline menunjukan bahwa kemampuan membaca permulaan subjek sudah berubah. Terlihat dari kemampuan membaca huruf, suku kata, kata dan kalimat sederhana subjek yang semakin bertambah walaupun pada beberapa komponen atau indikator subjek masih rendah seperti pada membaca kalimat sederhana. Namun dengan bertambahnya kemampuan membaca permulaan tersebut, sangat berpengaruh terhadap kemampuan akademik dalam membaca permulaannya, telihat dari banyak sesi pada akhir penelitian komponen kemampuan membaca huruf, suku kata 
dan kata menunjukan yang bertambah secara signifikan dibandingkan dengan kemampuan awal.

Data tumpang tindih (overlap) dalam analisis antar kondisi $A 1 / B, B / A 2$, dan A1/A2 memiliki arti semakin kecil presentase overlap menunjukkan semakin besar pengaruh intervensi terhadap perilaku sasaran. Pengaruh metode pembelajaran struktural analitik sintetik terhadap peningkatan kemampuan membaca permulaan dapat dilihat dari berbagai macam grafik di atas terutama pada grafik mean level kemampuan membaca permulaan dapat berpengaruh. Kemampuan membaca permulaan subjek mengalami peningkatan yang cukup signifikan.

\section{E. KESIMPULAN}

Berdasarkan hasil penelitian yang dilakukan dan data-data yang diperoleh dari lapangan yang meneliti tentang pengaruh metode struktural analitik sintetik terhadap peningkatan kemampuan membaca permulaan anak cerebral palsy spastik quadriplegia ringan yang diiringi dengan hambatan kecerdasan di SLB Risantya Kota Bandung kelas IX SMPLB, dapat disimpulkan bahwa metode pembelajaran struktural analitik sintetik berpengaruh secara signifikan terhadap peningkatan kemampuan membaca permulaan pada subjek tersebut. Hal tersebut berdasarkan hasil analisis pada setiap indikator pada komponen membaca permulaan yaitu membaca huruf, membaca suku kata, membaca kata dan membaca kalimat sederhana baik pada fase baseline 1 (A1), fase intervensi $(B)$, dan fase baseline 2 (A2) mengalami peningkatan. Rekomendasinya penelitian selanjutnya dapat menggunaka metode ini untuk meningkatkan kemampuan membaca permulaan anak.

\section{DAFTAR PUSTAKA}

Abidin, Y. (2010). Strategi membaca. Bandung: Rizqi Press.

Baso, S. A. A., Efendi, E., \& Barasandji, S. Peningkatan Kemampuan Siswa Membaca Permulaan Melalui Metode SAS di Kelas II SDN Pinotu. Jurnal Kreatif Online, 2(1).

Chaer, A. (2015). Fonologi Bahasa Indonesia. Jakarta: Rineka Cipta.

Irdawati, I., Yunidar, Y., \& Darmawan, D. Meningkatkan Kemampuan Membaca Permulaan Dengan Menggunakan Media Gambar Kelas 1 di Min Buol. Jurnal Kreatif Online, $5(4)$.

Kurniawan, O., \& Noviana, E. (2016). Metode Membaca Sas (Struktural Analitik Sintetik) dalam Meningkatkan Keterampilan Membaca Permulaandi Kelas I Sdn 79 Pekanbaru. Primary: Jurnal Pendidikan Guru Sekolah Dasar, 5(2), 149-157.

Muslich, M. (2017). Fonologi Bahasa Indonesia. Jakarta: Bumi Aksara.

Muslim. A, Sugiarmin. M. (1996). Ortopedi dalam Pendidikan Anak Tunadaksa. DEPDIKBUD.

Rosmana, I.A. (tanpa tahun). BB2: Cara membentuk fonem bahasa Indonesia (pdf). (online). Direktori UPI. Tersedia di: http://file.upi.edu/Direktori/DUALMODES/KEBAHASAAN_l/BBM_2_KB1\%2C_KB2.pdf

Rosyana, D. (2015). Penerapan Strategi DRTA (Directed Reading Thinking Activity) untuk Meningkatkan Kemampuan Membaca Pemahaman Siswa. (Doctoral dissertation, Universitas Pendidikan Indonesia). 
Setyani, W.. (2012). Metode Sas (Struktural Analitik Sintetik) Dalam Peningkatan Membaca Permulaan Di Kelas I Sekolah Dasar. KALAM CENDEKIA PGSD KEBUMEN, 1(1).

Styadhani, R. L. (2015). Peningkatan Kemampuan Membaca Permulaan melalui Media Kartu Kata Bergambar di Kelas B1 TK ABA Gedongkiwo Mantrijeron Yogyakarta. Pendidikan Guru PAUD S-1.

Sugiyono. (2014). Metode Penelitian Kuantitatif, Kualitatif dan R\&D. Bandung: Alfabeta.

Sunanto, J. (2005). Pengantar Penelitian dengan Subjek Tunggal. University of Tsukuba : Criced.

Supriyadi. (1992). Pendidikan Bahasa Indonesia 2. Jakarta: Depdikbud.

Tarigan, H.G. (2015). Membaca. Bandung: Angkasa. 